\title{
Microarray analysis revealed different gene expression patterns in HepG2 cells treated with low and high concentrations of the extracts of Anacardium occidentale shoots
}

\author{
Shaghayegh Khaleghi • Azlina Abdul Aziz • \\ Nurhanani Razali $\cdot$ Sarni Mat Junit
}

Received: 23 November 2010/Accepted: 11 March 2011/Published online: 29 March 2011

(C) The Author(s) 2011. This article is published with open access at Springerlink.com

\begin{abstract}
In this study, the effects of low and high concentrations of the Anacardium occidentale shoot extracts on gene expression in liver HepG2 cells were investigated. From MTT assays, the concentration of the shoot extracts that maintained $50 \%$ cell viability $\left(\mathrm{IC}_{50}\right)$ was $1.7 \mathrm{mg} / \mathrm{ml}$. Cell viability was kept above $90 \%$ at both $0.4 \mathrm{mg} / \mathrm{ml}$ and $0.6 \mathrm{mg} / \mathrm{ml}$ of the extracts. The three concentrations were subsequently used for the gene expression analysis using Affymetrix Human Genome 1.0 S.T arrays. The microarray data were validated using real-time qRT-PCR. A total of 246, 696 and 4503 genes were significantly regulated $(P<0.01)$ by at least 1.5 -fold in response to $0.4,0.6$ and $1.7 \mathrm{mg} / \mathrm{ml}$ of the extracts, respectively. Mutually regulated genes in response to the three concentrations included CDKN3, LOC100289612, DHFR, VRK1, CDC6, AURKB and GABRE. Genes like CYP24Al, BRCAl, AURKA, $C D C 2, C D K 2, C D K 4$ and INSR were significantly regulated at $0.6 \mathrm{mg} / \mathrm{ml}$ and $1.7 \mathrm{mg}$ but not at $0.4 \mathrm{mg} / \mathrm{ml}$. However, the expression of genes including LGR5, IGFBP3, RB1, IDE, LDLR, MTTP, APOB, MTIX, SOD2 and $S O D 3$ were exclusively regulated at the $\mathrm{IC}_{50}$ concentration. In conclusion, low concentrations of the extracts were able to significantly regulate a sizable number of genes. The type of genes that were expressed was highly dependent on the concentration of the extracts used.
\end{abstract}

Keywords Anacardium occidentale shoots .

Methanol extracts · Gene expression .

cDNA microarray analysis $\cdot$ HepG2 cells

S. Khaleghi · A. A. Aziz · N. Razali · S. M. Junit $(\bowtie)$ Department of Molecular Medicine, Faculty of Medicine, University of Malaya, 50603 Kuala Lumpur, Malaysia e-mail: sarni@um.edu.my

\section{Introduction}

The cashew plant or Anacardium occidentale L (A. occidentale) has many medicinal properties that are beneficial to health. Various scientific evidences have linked the various parts of cashew plant to several biological activities. The stem bark extract had been shown to have anti-bacterial [1], anti-viral [22], anti-diabetic [32] and anti-inflammatory [29] activities. Anti-tumour activity was detected in the cashew gum [30] and nut [42] while antiulcerogenic was reported in the cashew leaf extracts [19]. Antioxidant activities were also detected in the nut skin extracts [16]. In addition to the medicinal properties, the fruit of the A. occidentale is a natural whitening agent that disrupts pigmentation through the inhibition of tyrosinase [21].

In Malaysia, the young leaves or shoots of the A. occidentale are widely consumed as salads, and the locals believed its benefits include diabetic control and prevention. The extracts of the shoots were found to have potent antioxidant activities [35], were able to inhibit the oxidation of LDL and up-regulated LDL receptor activity in cultured HepG2 cells [39]. The antioxidant activities observed in the A. occidentale shoot extracts were attributed to the reported presence of phenolic compounds such as myricetin and quercetin [19, 27]. Intact quercetin glycosides, the most common flavonoids found in human diets, were shown to be absorbed at the small intestine probably through a sodium-dependent glucose transport pathway $[9,14]$. Once absorbed, quercetin circulates in the plasma in conjugated forms but its antioxidant properties were maintained [25].

Other active compounds found in the crude extracts of the A. occidentale leaves include catechin, epicatechin, tetramer of proanthocyanidin and biflavanoids amentoflavone [19] 
and agathisflavone [20]. Agathisflavone was reported to be able to induce apoptosis in Jurkat cells (acute lymphoblastic leukaemia cell line) [20] as well as a potent, competitive inhibitor for the $\mathrm{GABA}_{\mathrm{A}}$ /benzodiazepine receptor [43].

Scientific molecular studies on the effects of the A. occidentale shoot extracts on cells are still lacking despite its reported antioxidant properties and its use in traditional medicine. We had earlier reported that the methanol extracts of the $A$. occidentale contained the highest total phenolic content compared to ethyl acetate and hexane extracts [35]. In this study, we explored the effects of the methanol extracts of the A. occidentale shoots on the expression of genes which could be associated with its antioxidant and medicinal properties.

\section{Materials and methods}

\section{Chemicals}

All reagents and chemicals used in the experiments were of analytical grade and obtained mostly from Sigma-Aldrich. Solvents used for extraction of plants were purchased from Fisher Scientific. Water used was of Millipore quality (ELGA Purelab Ultra Genetic system).

Preparation of methanol extract of the shoots of Anacardium Occidentale

In our previous study [35], we reported that the methanol extract of the A. Occidentale shoots possessed significantly higher antioxidant activities compared to those of the ethyl acetate and hexane extracts. The methanol extracts was subsequently used in this study. Briefly, the shoots were washed, air-dried followed by complete drying in an oven at $40^{\circ} \mathrm{C}$. The dried shoots were then ground to powder and then extracted with methanol with a mass to volume ratio of 1:20 $(\mathrm{g} / \mathrm{mL})$, at room temperature for $24 \mathrm{~h}$. The resulting extract was filtered and roto-evaporated (Rotavapor R-215) to dryness at $37^{\circ} \mathrm{C}$, and the residues were then redissolved in dimethylsulfoxide (DMSO). For the subsequent cell culture experiments, the final concentration of DMSO was kept below $1 \%$ to avoid toxicity to the cells.

High-performance liquid chromatography

Acid hydrolyses was conducted on the dried powder of A. occidentale [3]. Samples (20 mg) were mixed with $50 \%$ methanol containing $1.2 \mathrm{M} \mathrm{HCl}$ and $20 \mathrm{mM}$ sodium diethyldithiocarbamate as an antioxidant, in reactive vials. The samples were hydrolysed for $2 \mathrm{~h}$ at $90^{\circ} \mathrm{C}$. Following hydrolysis, samples were centrifuged at $5000 \times g$ for $5 \mathrm{~min}$ and diluted with distilled water $(\mathrm{pH} 2.5)$ prior to analysis on the HPLC. The hydrolysed samples contained both free flavonoids and aglycones released from conjugated flavonoids following acid hydrolysis.

The HPLC system used for the flavonoid analyses comprised a Shimadzu system consisting of a system controller, a binary pump (LC 20AC), a manual injector (Rheodyne $7725 \mathrm{i}$ manual injector), a column oven (CTO-10AS VP) and a dual channel UV detector (SPD20A UV-VIS). Absorbance of the samples was monitored at a wavelength of $260 \mathrm{~nm}$. Flavonoids in the samples were separated using a reversed-phase column (NovaPak $\mathrm{C}_{18}$, $150 \times 3.0 \mathrm{~mm}$, i.d $4 \mu \mathrm{m}$ ) (Waters, USA), at a temperature of $40^{\circ} \mathrm{C}$. Separation of flavonoids was conducted using a gradient system containing $7-40 \%$ acetonitrile in water $(\mathrm{pH} 2.5$ ) at a flow rate of $0.5 \mathrm{ml} / \mathrm{min}$ over $20 \mathrm{~min}$. Standard solutions containing catechin, epicatechin, rutin, genistin, myricetin, morin, quercetin, genistein, kaempferol and isorhamnetin were prepared and injected on the HPLC under the same conditions.

\section{Cell culture}

The human hepatoblastoma HepG2 cell line (ATCC, Manassas, VA, USA) was grown in Dulbecco's modified Eagle's medium (DMEM) supplemented with $10 \%$ foetal bovine serum (Flowlab, Australia), 1\% penicillin (Flowlab, Australia) and 1\% streptomycin (Flowlab, Australia). Cells were maintained in humidified air with $5 \% \mathrm{CO}_{2}$ at $37^{\circ} \mathrm{C}$.

\section{Cell viability analysis using the MTT assay}

Cell viability of HepG2 cells in response to treatment with various concentration of the $A$. occidentale shoot extracts was analysed using an MTT assay as described by Mosmann, 1983 [28] with slight modifications [36]. Briefly, HepG2 cells at a density of 5000 cells per well were seeded in a 96-well ELISA microplate. The cells were incubated at $37^{\circ} \mathrm{C}$ in $5 \% \mathrm{CO}_{2}$ for $24 \mathrm{~h}$. After $24 \mathrm{~h}$, increasing concentrations of the shoots extracts $(0.2-5.0 \mathrm{mg} / \mathrm{ml})$ were added into the wells, and the cells were further incubated for $48 \mathrm{~h}$. Following this, MTT reagent (Merck) was added, and the mixture was incubated for $4 \mathrm{~h}$. Next, the mixture in each well was removed, and formazan crystals formed were dissolved in $10 \mu \mathrm{l}$ of $75 \%$ isopropanol. Spectrophotometric measurement of the mixture was performed in a microplatereader (Bio-Rad) at 590 and $620 \mathrm{~nm}$ wavelengths. A linear plot of cell viability (\%) against the concentrations of plant extracts was constructed.

Treatment of HepG2 cells for the microarray analysis

For the gene expression analysis, 80-95\% confluent HepG2 cells maintained in DMEM were treated with shoot extracts 
at $0.4,0.6$ and $1.7 \mathrm{mg} / \mathrm{ml}$. The cells were then incubated at $37^{\circ} \mathrm{C}$ for $24 \mathrm{~h}$. As a control, cells were incubated in fresh DMEM, in the absence of the extracts. All experiments were performed in triplicate. After $24 \mathrm{~h}$, cells were trypsinized and then precipitated by centrifugation at $261 \times g$ for $5 \mathrm{~min}$. Following this, cells were washed with PBS twice before total cellular RNA (tcRNA) was extracted from the treated and untreated cells.

\section{Extraction of total cellular RNA (tcRNA)}

tcRNA from both treated and untreated (control) HepG2 cells was isolated and then purified using RNAEasy kit and RNase-free DNAse set (Qiagen) according to the manufacturer's instructions. The quality of the tcRNA was estimated by measuring the absorbance ratio of 260-280 nm while its integrity was analysed using denaturing gel electrophoresis. An A260/A280 ratio above 1.8 indicated that the tcRNA was of good quality. The integrity of the tcRNA was indicated by the presence of two distinct bands corresponding to the ribosomal $28 \mathrm{~S}$ and $18 \mathrm{~S}$ subunits, with the intensity of the larger, $28 \mathrm{~S}$ band approximately twice than that of the smaller, $18 \mathrm{~S}$ band.

\section{Microarray analysis}

Affymetrix Human Gene 1.0 S.T (sense target) arrays were used for the gene expression analysis according to the conventional Affymetrix eukaryotic RNA labelling protocols (Affymetrix). Briefly, freshly extracted tcRNA (100 ng) isolated from the treated and untreated HepG2 cells was reversed transcribed to single-stranded sense strand DNA (cDNA) in two cycles using the Whole Transcript (WT) cDNA synthesis, amplification kit and sample clean-up module. The sense strand cDNA was then cleaved into small fragments using a mixture of UDP and apurinic/apyrimidinic endonuclease 1 or APE1. Following this, the fragments were end-labeled with biotinylated dideoxynucleotides using the WT Terminal Labeling kit. The biotinylated fragments $(5.5 \mu \mathrm{g})$ were then hybridized to the Affymetrix Human Gene 1.0 S.T array at $45^{\circ} \mathrm{C}$ for $16 \mathrm{~h}$ in hybridization Oven 640. After hybridization, the arrays were stained and then washed in the Affymetrix Fluidics Station 450 under standard conditions. The stained arrays were scanned at $532 \mathrm{~nm}$ using an Affymetrix GeneChip Scanner 3000, and CEL files for each array were generated using the Affymetrix GeneChip ${ }^{\circledR}$ Operating Software (GCOS). The data were preanalyzed using Affymetrix Expression Console software.

Microarray data normalization and analysis

The CEL files generated were converted to text files and exported to Partek Genomic Suite software to get the whole list of up-regulated and down-regulated genes. Probeset IDs without any annotation in the Partek software were filtered out. The filtered, whole gene list was then subjected to a one-way analysis of variance (ANOVA) in the Partek Genomic software, to determine significantly expressed sets of genes which was set according to $P$ values less than $0.01(P<0.01)$ instead of $P<0.05$ to avoid false positive results. Significantly expressed genes were then re-filtered to include only those with fold change difference of equal to or greater than 1.5. Additional information on the biological functions of the genes and the genes products was determined from the Gene Ontology (GO) Enrichment tool in the Partek Genomic Suite Software. Information on function of genes can be derived from the Gene Ontology database which provides a structured annotation of genes with respect to molecular function, biological process and cellular component. Further information on GO could be retrieved from http://www.geneontology.org/.

Validation of the DNA microarray data using qRT-PCR

The microarray data were verified using real-time relative quantitative RT-PCR (qRT-PCR) which was performed in a StepOne ${ }^{\mathrm{TM}}$ Real-Time PCR System (Applied BioSystem). The same cDNA and primer pairs for the selected up-regulated and down-regulated genes as well as a housekeeping gene, GADPH, as listed in Table 1 were used. The PCR amplification was carried out in $0.2 \mathrm{ml}$ MicroAmp ${ }^{\circledR}$ Optical 8-tube strips in a final volume of $20 \mu \mathrm{l}$ containing a mixture of cDNA (30 ng), reverse and forward primers $(1 \mu \mathrm{M})$, pre-prepared Power SYBR ${ }^{\circledR}$ Green PCR master mix containing SYBR ${ }^{\circledR}$ Green 1 dye, AmpliTaq Gold ${ }^{\circledR}$ DNA Polymerase dNTPs, dUTP, Passive Reference 1 and optimized buffer components. The PCR parameters consisted of 40 cycles of amplification with initial denaturation at $95^{\circ} \mathrm{C}$ for $15 \mathrm{~s}$, annealing of primers and elongation of the newly synthesized strands at $60^{\circ} \mathrm{C}$ for $60 \mathrm{~s}$. The PCR mixture was initially held for $10 \mathrm{~min}$ at $95^{\circ} \mathrm{C}$ for AmpliTaq Gold $^{\circledR}$ DNA polymerase activation. The Comparative $\mathrm{C}_{\mathrm{T}}$ Method $\left(\Delta \Delta \mathrm{C}_{\mathrm{T}}\right)$ was chosen for the relative quantitation of gene expression. Each sample type was run in triplicate. mRNA levels of the selected genes were normalized against that of $G A D P H$.

\section{Results}

Cell viability analysis

MTT assays were performed to measure the viability of the cells in response to the treatment with different concentrations of the shoot extracts. The dose-response curve of 
Table 1 Primer sequences for the selected genes used for validation of the microarray data using real-time relative quantitative PCR (qRT-PCR)

\begin{tabular}{|c|c|c|}
\hline Gene name (Genebank ID) & Primer sequences & Product size $(\mathrm{bp})$ \\
\hline DHFR (NM_000791) & $\begin{array}{l}\text { Forward: } 5^{\prime} \text { CATGGTCTGGATAGTTGGTGGC } 3^{\prime} \\
\text { Reverse: } 5^{\prime} \text { GTGTCACTTTCAAAGTCTTGCATG } 3^{\prime}\end{array}$ & 108 \\
\hline TYMS (NM_001071) & $\begin{array}{l}\text { Forward: } 5^{\prime} \text { ATCAAGGGATCCACAAATGA } 3^{\prime} \\
\text { Reverse: } 5^{\prime} \text { GGTCAACTCCCTGTCCTGAA } 3^{\prime}\end{array}$ & 205 \\
\hline LIPC (NM_000236) & $\begin{array}{l}\text { Forward: } 5^{\prime} \text { CAAGTGCCCTTGGACAAAGC } 3^{\prime} \\
\text { Reverse: } 5^{\prime} \text { TGACAGCCCTGATTGGTTTCT } 3^{\prime}\end{array}$ & 130 \\
\hline CYP24A1 (NM_000782) & $\begin{array}{l}\text { Forward: } 5^{\prime} \text { CTCATGCTAAATACCCAGGTG } 3^{\prime} \\
\text { Reverse: } 5^{\prime} \text { TCGCTGGCAAAACGCGATGGG } 3^{\prime}\end{array}$ & 300 \\
\hline PLAUR (NM_002659) & $\begin{array}{l}\text { Forward: } 5^{\prime} \text { TGCGGTGCATGCAGTGTAAGAC } 3^{\prime} \\
\text { Reverse: } 5^{\prime} \text { TCAAGCCAGTCCGATAGCTCAG } 3^{\prime}\end{array}$ & 183 \\
\hline PLCXD1 (NM_018390) & $\begin{array}{l}\text { Forward: } 5^{\prime} \text { ACGAGTACCTGGTCGCCTGTAT } 3^{\prime} \\
\text { Reverse: } 5^{\prime} \text { CATAGGAGACGATGACCTGTTGG } 3^{\prime}\end{array}$ & 117 \\
\hline SQSTM1 (NM_003900) & $\begin{array}{l}\text { Forward: } 5^{\prime} \text { CCAGTGACGAGGAATTGACAA } 3^{\prime} \\
\text { Reverse: } 5^{\prime} \text { CATCGCAGATCACATTGGGG } 3^{\prime}\end{array}$ & 156 \\
\hline
\end{tabular}

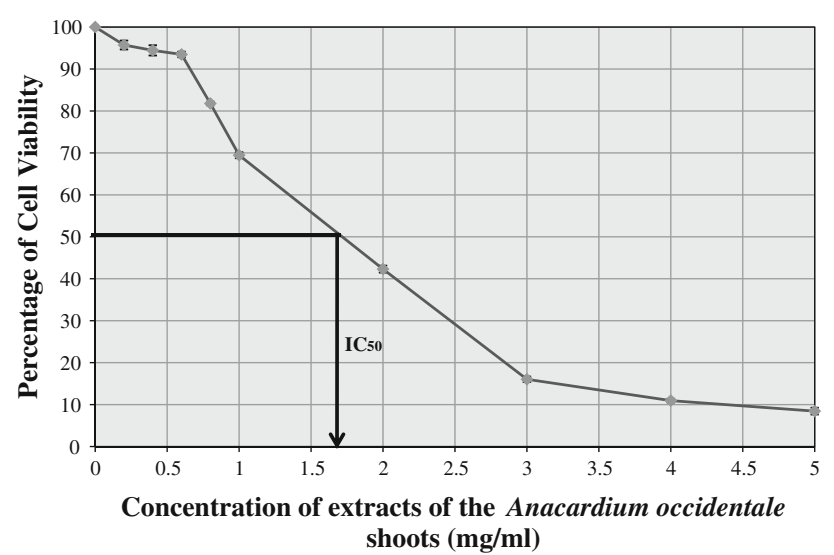

Fig. 1 A dose-response curve of percentage viability of HepG2 cells $(5,000$ cells/well $)$ treated with various concentrations of the extract of the A. occidentale shoots $(0.2-5.0 \mathrm{mg} / \mathrm{ml})$. Analysis was done in triplicate, and the results were expressed as \% of HepG2 cell viability \pm std dev. From the plot, the $\mathrm{IC}_{50}$ was found to be $1.7 \mathrm{mg} / \mathrm{ml}$

the viability of HepG2 cells in response to the treatment with different concentrations of the methanol extract of A. occidentale shoots is shown in Fig. 1. The graph shows a tri-phasal response. In the first phase, cell viability was maintained above $90 \%$ until $0.6 \mathrm{mg} / \mathrm{ml}$ of the extract concentration was reached. In the second phase, cell viability decreased steeply to below $20 \%$ from 0.6 to $3 \mathrm{mg} / \mathrm{ml}$ extract concentrations. In the third phase, the cells barely survived (viability below 10\%) beyond $5 \mathrm{mg} / \mathrm{ml}$ extract concentration. The concentration of the shoot extract that reduced cell viability by $50 \%\left(\mathrm{IC}_{50}\right)$ was $1.7 \mathrm{mg} / \mathrm{ml}$. Low concentrations of 0.4 and $0.6 \mathrm{mg} / \mathrm{ml}$ as well as the $\mathrm{IC}_{50}$ concentration were subsequently chosen for the gene expression analysis.
HPLC analysis

HPLC analyses of the hydrolysed samples revealed the presence of quercetin and kaempferol (Fig. 2a) and the absence of catechin, epicatechin, rutin, genistin, genistein, myricetin, morin and isorhamnetin. The quercetin and kaempferol peaks were confirmed by comparing retention times of the peaks with the standards (Fig. 2b) which was run under the same conditions as the samples. The presence of kaempferol has not been reported previously.

Microarray analysis: normalization and visualization of data

Figure 3 shows the principal component analysis (PCA) plot of the microarray data for each of the array for the control and samples treated with $0.4,0.6$ and $1.7 \mathrm{mg} / \mathrm{ml}$ of the shoot extracts. The three arrays for the control samples were grouped together but separately from those of the treated samples. Figure 4 shows hierarchical clustering of the microarray data generated from each of the arrays where the reproducibility pattern correlates with that shown by the PCA plot.

Venn diagram in Fig. 5 shows the number of genes that were significantly regulated $(P<0.01)$ by at least 1.5 -fold. The total number of genes regulated by $0.4,0.6$ and $1.7 \mathrm{mg} / \mathrm{ml}$ of the methanol extracts of A. occidentale were 246, 696 and 4,503, respectively. An increase in concentration by 1.5 -fold from 0.4 to $0.6 \mathrm{mg} / \mathrm{ml}$ was able to increase the number of regulated genes by threefold $(65 \%)$. In addition, increasing the concentration from 0.4 to $1.7 \mathrm{mg} / \mathrm{ml}$ increased the number of regulated genes by 18 -fold (95\%). Figure 5 also shows that a total of 94 genes were mutually regulated in response to the three 

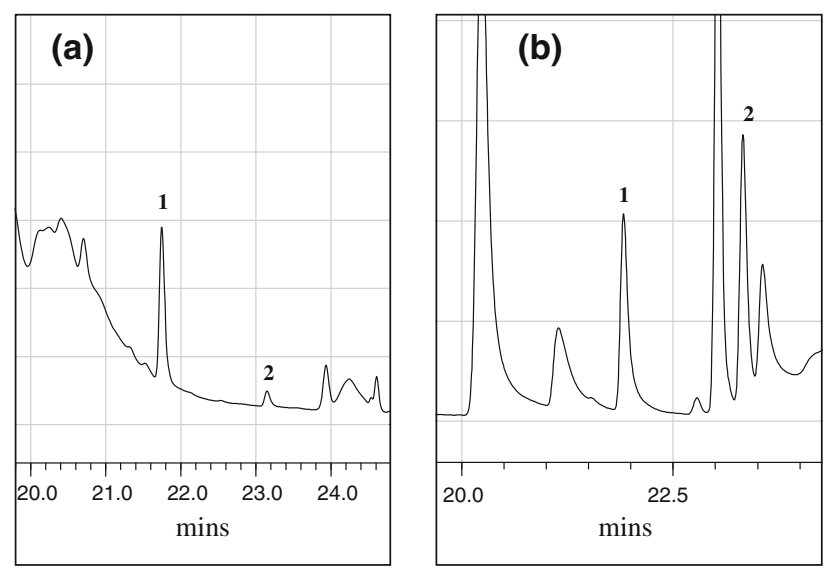

Fig. 2 Gradient reverse phase HPLC analysis of flavonoids in the shoots of A. occidentale and the flavonoid standards. HPLC analysis was performed on the hydrolysed samples of A. occidentale (Fig. 2a) and the flavonoid standards (Fig. 2b). Flavonoids were separated on a NovaPak $\mathrm{C}_{18}$ reversed-phase column $(150 \times 3.0 \mathrm{~mm}$ i.d, $4 \mu \mathrm{m})$, using a linear gradient system of $7-40 \%$ acetonitrile in water $(\mathrm{pH}$ 2.5 ), at a flow rate of $0.5 \mathrm{ml} / \mathrm{min}$. Absorbance was measured at a wavelength of $260 \mathrm{~nm}$. 1:quercetin; 2:kaempferol

concentrations where 5 were up-regulated and 89 were down-regulated. Ninety-eight genes were mutually regulated in response to the 0.4 and $0.6 \mathrm{mg} / \mathrm{ml}$ extracts. On the other hand, 178 were mutually regulated in response to the 0.4 and $1.7 \mathrm{mg} / \mathrm{ml}$ extracts. A larger number of genes, with a total of 571 , were regulated when cells were treated with 0.6 and $1.7 \mathrm{mg} / \mathrm{ml}$ of the extracts.

Mutually regulated genes in response to the three concentrations included CDKN3, LOC100289612, DHFR,
VRK1, CDC6, AURKB, CYP2S1 and GABRE (Table 2). Genes like CYP24A1, CDH2, E2F5, BRCA1, BRCA2, AURKA, CDC2 (CDK1), CDK2, CDK4, CHECK1, CCNA2, ACAT, IGFBP1, DUSP5 and INSR were significantly regulated at 0.6 and $1.7 \mathrm{mg} / \mathrm{ml}$ but not at $0.4 \mathrm{mg} / \mathrm{ml}$. In addition, the expressions of genes such as the $L G R 5$, IGFBP3, RB1, IDE, LDLR, MTTP, APOB, SCP2, MTIX, $S O D$ and $S O D 3$ were exclusively regulated at the $1.7 \mathrm{mg} /$ $\mathrm{ml}$ dose. Amongst the highly significantly suppressed genes were CYP24A1, LGR5, CDH2 and DHFR by 27.8-, 16.4-, 15.5-, 10.0-fold, respectively. On the other hand, amongst the highly induced genes were the DUSP5, IGFBP 3, IGFBPI, LDLR and INSR by 9.1-, 8.0-, 4.2-, 3.6- and 2.6-fold, respectively (Table 2).

Other genes that were being significantly regulated in response to the $1.7 \mathrm{mg} / \mathrm{ml}$ shoot extracts were those associated with cell cycle check points either directly or indirectly. These included the $C D K 5, C D K 6, C C N B 1$ and 2, CCNE1 and 2, CCNH, CDKN1A (p21/Cip1), CDKNIC (p57/Kip2), CDKN2B (p15), CDKN2D (p19), CDKN3, RBL1, RBL2, NSUN6, NOP2, DAPK1, PAK2, HDAC2 and G2E3. Genes coding for other ubiquitin ligase isoforms, $U B E 2 C$ and $U B E 3 B$, were also aberrantly expressed. In addition, genes associated with the $\mathrm{Wnt} / \beta$-catenin signalling pathway including the Wnt6, FZDs $1,4,6,7,8,9$ and 10, CDH1, CTNNA2, DKK1, APC, NUCKS1, CSNK1G2, CSNKIG3 and TCF were all aberrantly expressed. In addition, genes associated with cancers, BRIP1, BAP, BRCC3, RAS, SOS1, STAT2, were all down-regulated (data not shown).
Fig. 3 A principal component analysis (PCA) plot derived from biological replicates $(n=3)$ of HepG2 cells grown in $0.4,0.6$ and $1.7 \mathrm{mg} / \mathrm{ml}$ of the extracts of the A. occidentale shoots

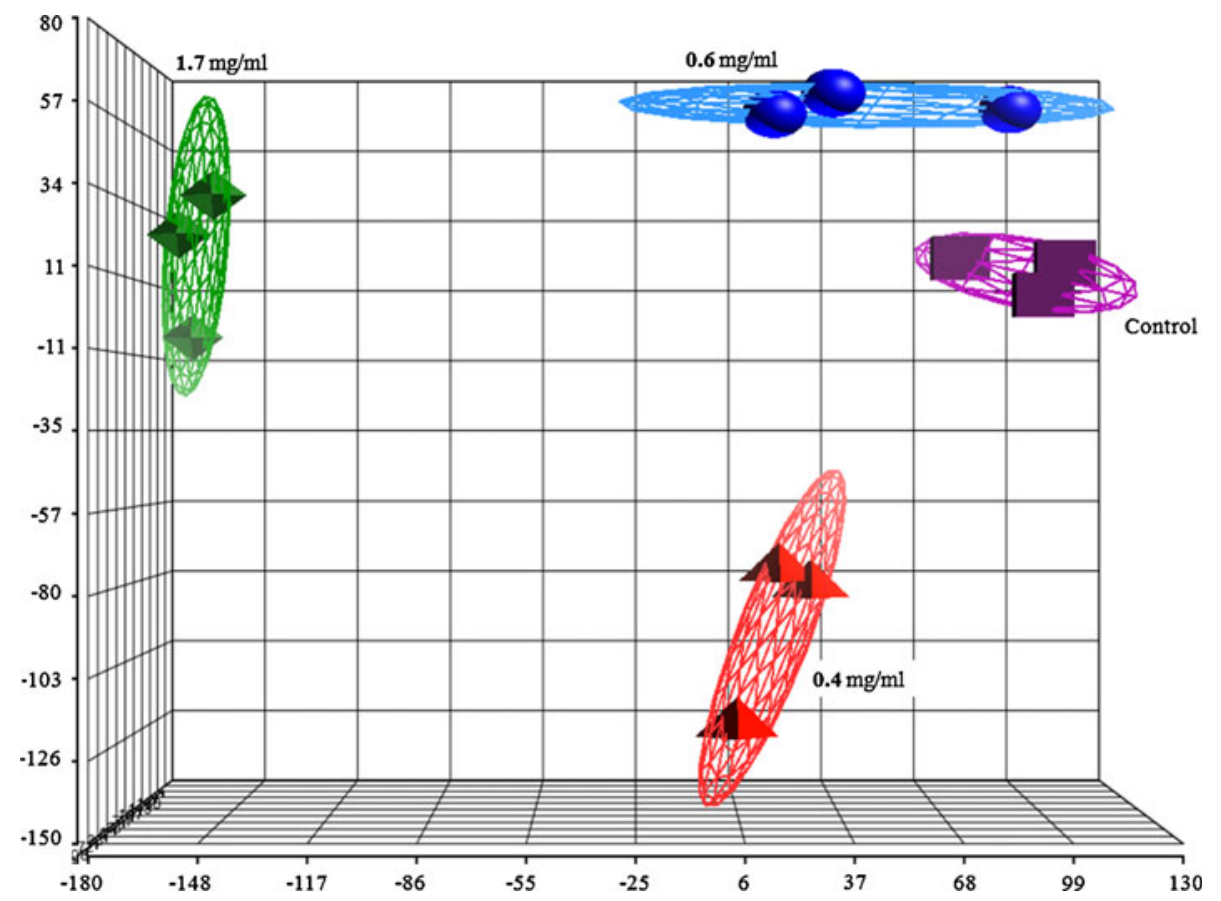




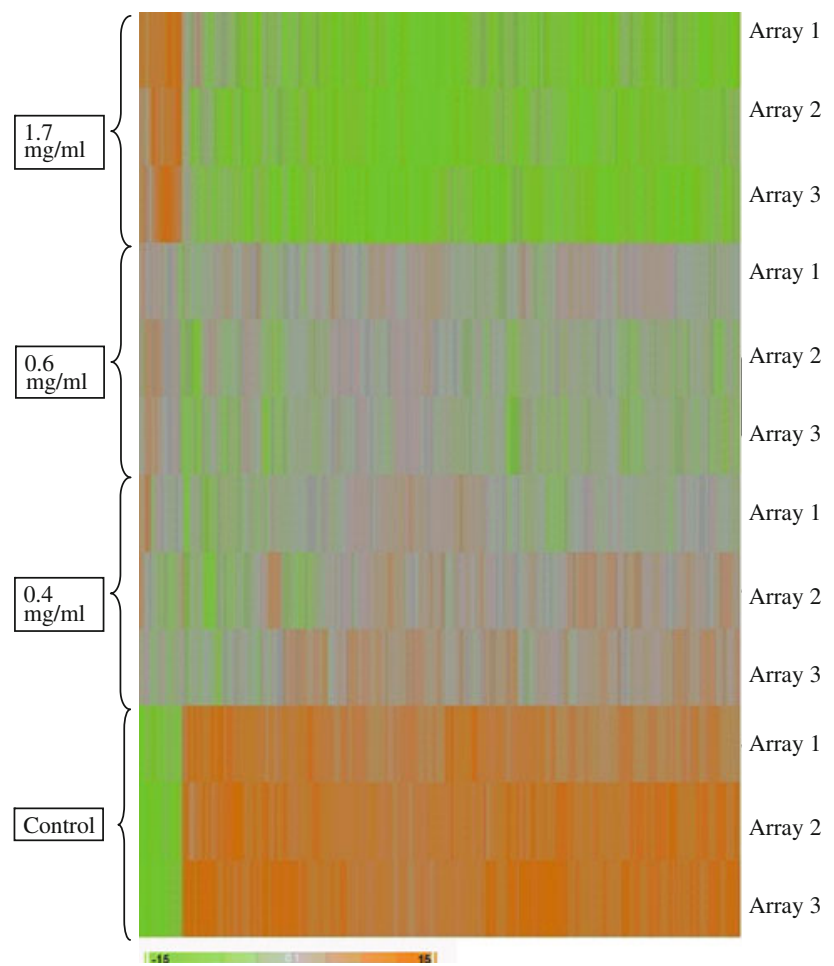

Fig. 4 Hierarchical cluster analysis of genes showing the differential expression of genes in HepG2 cells in response to the treatment with $0.4,0.6$ and $1.7 \mathrm{mg} / \mathrm{ml}$ of extracts of A. occidentale shoots

\section{Gene ontology (GO): biological interpretation}

Gene ontology analysis of the products of the significantly regulated genes in response to the 3 concentrations of the A. occidentale shoot extracts is shown in Figs. 6, 7 and 8. The data are presented according to the following categories; biological process (Fig. 6), molecular function (Fig. 7) and cell component (Fig. 8). Selected significantly down-regulated and up-regulated genes in each of the category are shown in Table 3.

Figures 6,7 and 8 show that most of the genes (and the subsequent gene products) are involved in cellular processes, biological regulations and metabolic processes in response to the three concentrations of the extracts. A total of 18 genes that are involved in localization, growth, locomotion and pigmentation were regulated in response to the $0.6 \mathrm{mg} / \mathrm{ml}$ but not the $0.4 \mathrm{mg} / \mathrm{ml}$ extracts. As the concentration was increased from 0.6 to $1.7 \mathrm{mg} / \mathrm{ml}$, the number of genes rose from 18 to 88 in the same 3 subcategories. In addition, 3 genes that are involved in reproduction were regulated only in the presence of $1.7 \mathrm{mg} / \mathrm{ml}$ of the extracts. Genes like CYP24A1 and DHFR are involved in cellular as well as metabolic processes (Table 3A). In addition, under the "Molecular function" category, the majority of genes that were regulated in response to the 3 concentrations were involved in binding, followed by catalytic activity and transcriptional regulation activity (Fig. 7). Table 3B lists

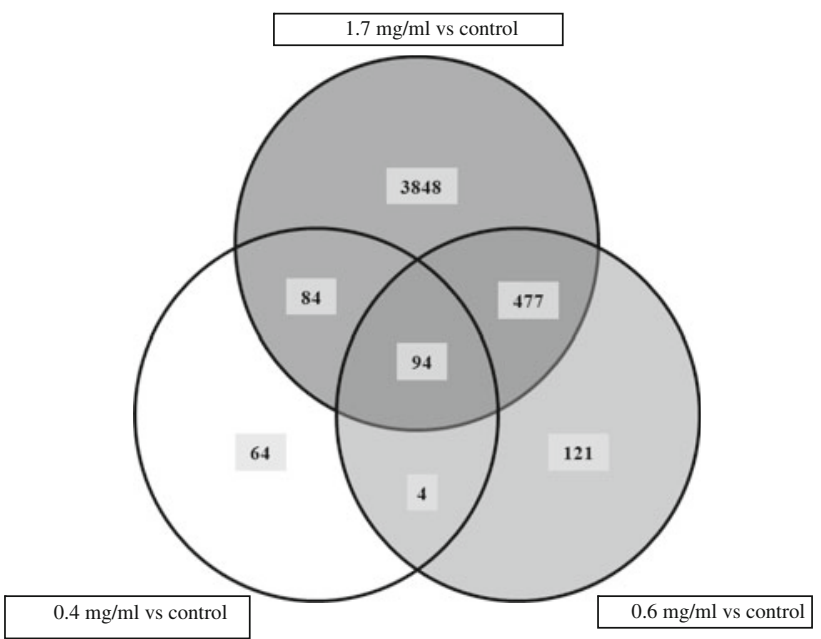

Fig. 5 A Venn diagram illustrating the number of genes in HepG2 cells that were mutually regulated at $0.4,0.6$ and $1.7 \mathrm{mg} / \mathrm{ml}$ of the shoot extracts. The total numbers of genes regulated at $0.4,0.6$ and $1.7 \mathrm{mg} / \mathrm{ml}$ of the extracts of A. occidentale were 246, 696 and 4503 respectively. An increase in concentration by 1.5 -fold from 0.4 to $0.6 \mathrm{mg} / \mathrm{ml}$ was able to increase the number of regulated genes by threefold (65\%). Increasing the concentration from 0.4 to $1.7 \mathrm{mg} / \mathrm{ml}$ increases the number of regulated genes by 18 -fold (95\%). A total of 94 genes were mutually regulated in response to the 3 concentrations, 5 were up-regulated and 89 were down-regulated. Ninety-eight genes were mutually regulated in response to the 0.4 and $0.6 \mathrm{mg} / \mathrm{ml}$ extracts. On the other hand, 178 were mutually regulated in response to the 0.4 and $1.7 \mathrm{mg} / \mathrm{ml}$ extracts. A larger number of genes of 571 were mutually regulated when cells were treated with 0.6 and $1.7 \mathrm{mg} / \mathrm{ml}$ extracts

selected genes such as INSR and $L D L R$ that are involved in binding, MAOB in catalytic activity and $R B 1$ in transcription regulator activity. The majority of the gene products were found as cell part, in extracellular region/part and in synapses (Fig. 8), and the selected genes are listed in Table 3C.

\section{Validation of the microarray data using qRT-PCR}

The microarray data were validated by quantitating selected significantly regulated genes, PLAUR, PLCXD1, SQSTM1, CYP24A1, DHFR, TYMS and LIPC using realtime RT-PCR (qRT-PCR). All data were normalized to the reference gene, GAPDH. As shown in Fig. 9, the expressions of the PLAUR, PLCXD1 and SQSTM1 genes were all up-regulated while those of CYP24A1, DHFR, TYMS and LIPC were down-regulated. The expression patterns obtained through qRT-PCR analysis were consistent with those of the microarray results.

\section{Discussion and conclusion}

In Malaysia, the young leaves or shoots of the A.occidentale are widely consumed as salads and the locals believed 
Table 2 Selected significantly expressed genes in HepG2 cells in response to treatment with $0.4,0.6$ and $1.7 \mathrm{mg} / \mathrm{ml}$ of the extracts of A. occidentale shoots

\begin{tabular}{|c|c|c|c|c|c|}
\hline Gene ID & Gene name & Gene product & $\begin{array}{l}\text { Fold change } \\
(0.4 \mathrm{mg} / \mathrm{ml})\end{array}$ & $\begin{array}{l}\text { Fold change } \\
(0.6 \mathrm{mg} / \mathrm{ml})\end{array}$ & $\begin{array}{l}\text { Fold change } \\
(1.7 \mathrm{mg} / \mathrm{ml})\end{array}$ \\
\hline NM_005192 & $C D K N 3$ & Cyclin-dependent kinase inhibitor 3 & -2.7 & -2.6 & -10.5 \\
\hline AY605064 & LOC100289612 & Arsenic transactivated protein 1 & -3.0 & -3.6 & -10.2 \\
\hline AK293146 & DHFR & Dihydrofolate reductase & -2.4 & -2.4 & -10.0 \\
\hline NM_003384 & VRK1 & Vaccinia related kinase 1 & -2.3 & -2.6 & -6.7 \\
\hline NM_001254 & CDC6 & Cell division cycle 6 homolog (S. cerevisiae) & -2.4 & -2.7 & -4.3 \\
\hline NM_030622 & $C Y P 2 S 1$ & Cytochrome P450, family 2, subfamily S, polypeptide 1 & +1.8 & +2.3 & +3.5 \\
\hline NM_004961 & GABRE & Gamma-aminobutyric acid (GABA) A receptor, epsilon & +1.6 & +2.1 & +2.7 \\
\hline NM_004217 & $A U R K B$ & Aurora kinase B & -1.6 & -1.6 & -2.2 \\
\hline NM_000782 & CYP24A1 & Cytochrome P450, family 24, subfamily A, polypeptide 1 & NR & -2.9 & -27.8 \\
\hline NM_001792 & $\mathrm{CDH} 2$ & Cadherin 2, type 1, N-cadherin (neuronal) & NR & -1.8 & -15.5 \\
\hline NM_001951 & $E 2 F 5$ & E2F transcription factor 5, p130-binding & NR & -1.9 & -5.5 \\
\hline NR_027676 & $B R C A 1$ & Breast cancer 1 , early onset & NR & -2.4 & -5.1 \\
\hline NM_000236 & $L I P C$ & Lipase, hepatic & NR & -3.2 & -4.7 \\
\hline NM_198433 & AURKA & Aurora kinase A & NR & -1.5 & -4.4 \\
\hline NM_001786 & $C D C 2$ & Cell division cycle $2, \mathrm{G} 1$ to $\mathrm{S}$ and $\mathrm{G} 2$ to $\mathrm{M}$ & NR & -2.5 & -4.1 \\
\hline NM_001798 & $C D K 2$ & Cyclin-dependent kinase 2 & NR & -2.0 & -3.2 \\
\hline NM_001237 & CCNA2 & Cyclin A2 & NR & -1.7 & -3.1 \\
\hline NM_000059 & $B R C A 2$ & Breast cancer 2, early onset & NR & -2.0 & -2.7 \\
\hline NM_000019 & $A C A T 1$ & Acetyl-coenzyme A acetyltransferase 1 & NR & -1.9 & -2.6 \\
\hline NM_000075 & $C D K 4$ & Cyclin-dependent kinase 4 & NR & -1.8 & -2.6 \\
\hline NM_001274 & CHEK1 & CHK1 checkpoint homolog (S. pombe) & NR & -1.8 & -2.3 \\
\hline NM_000208 & INSR & Insulin receptor & NR & +2.3 & +2.6 \\
\hline NM_000596 & $I G F B P 1$ & Insulin-like growth factor binding protein 1 & NR & +3.7 & +4.2 \\
\hline NM_004419 & DUSP5 & Dual specificity phosphatase 5 & NR & +3.3 & +9.1 \\
\hline NM_003667 & $L G R 5$ & Leucine-rich repeat-containing G protein-coupled receptor 5 & NR & NR & -16.4 \\
\hline NM_000321 & $R B 1$ & Retinoblastoma 1 & NR & NR & -7.6 \\
\hline NM_031966 & CCNB1 & Cyclin B1 & NR & NR & -5.7 \\
\hline NM_000253 & MTTP & Microsomal triglyceride transfer protein & NR & NR & -3.7 \\
\hline NM_002979 & $S C P 2$ & Sterol carrier protein 2 & NR & NR & -3.5 \\
\hline NM_004969 & $I D E$ & Insulin-degrading enzyme & NR & NR & -2.1 \\
\hline NM_000384 & $A P O B$ & Apolipoprotein B & NR & NR & -2.0 \\
\hline NM_001013398 & $I G F B P 3$ & Insulin-like growth factor binding protein 3 & NR & NR & +8.0 \\
\hline NM_000527 & $L D L R$ & Low-density lipoprotein receptor & NR & NR & +3.6 \\
\hline NM_005952 & MTIX & Metallothionein 1X & NR & NR & +2.8 \\
\hline NM_003102 & SOD3 & Superoxide dismutase 3 , extracellular & NR & NR & +2.1 \\
\hline
\end{tabular}

Details of the GenBank accession number, name of the gene and its respective gene product, fold change difference between treated and nontreated cells and $p$ values are included. $N R$ Not regulated

its benefits include diabetes control or prevention. The methanol extracts of the shoots were found to have potent antioxidant activities [35]. Bioactive compounds found in the A. occidentale shoot extracts that could be linked to the antioxidant activities and other medicinal properties included myricetin and quercetin [19,27], amentoflavone [19] and agathisflavone [20]. Dietary antioxidants could be absorbed through the intestine, albeit in small quantities. Once in the circulation, they are quickly metabolized
$[14,44]$ but the antioxidant properties were retained [25]. Our group had reported that low concentration of crude extract of antioxidant-rich $T$. indica $(0.3 \mathrm{mg} / \mathrm{ml})$ was able to significantly regulate a sizable number of genes in HepG2 cells [36]. In this study, based on the MTT assays, cells showed more than $90 \%$ viability at 0.4 and $0.6 \mathrm{mg} / \mathrm{ml}$. The $\mathrm{IC}_{50}$ concentration was found to be $1.7 \mathrm{mg} / \mathrm{ml}$. This study was aimed to (1) investigate the effects of low and high concentration of the A. occidentale shoot extracts on 


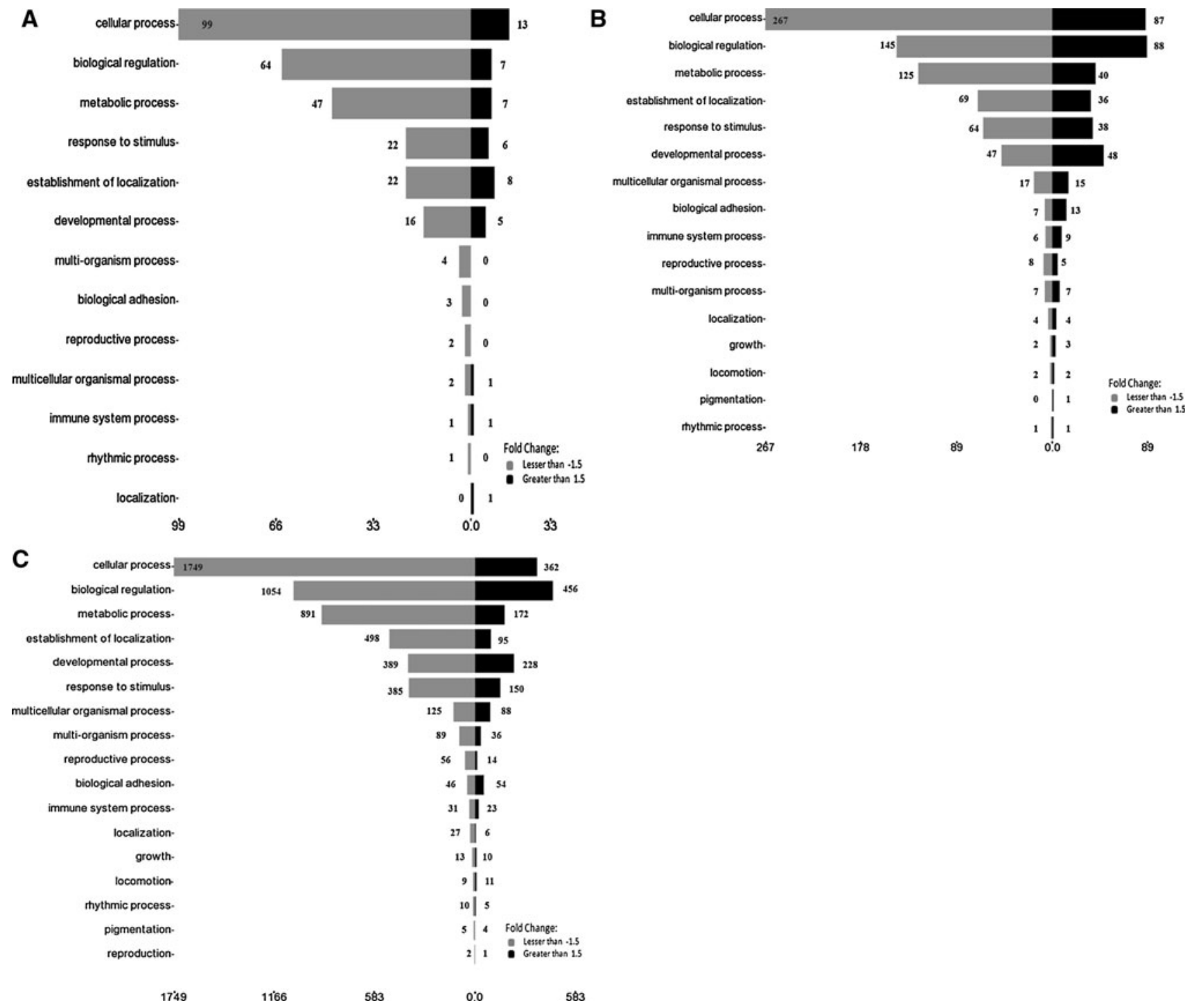

Fig. 6 Gene ontology analysis under the "Biological process" category, of significantly regulated genes $(P<0.01$, fold change of at least \pm 1.5$)$ in HepG2 cells in response to $0.4 \mathrm{mg} / \mathrm{ml}(\mathbf{a}), 0.6 \mathrm{mg} / \mathrm{ml}(\mathbf{b})$ and $1.7 \mathrm{mg} / \mathrm{ml}(\mathbf{c})$ of the extracts of A. occidentale shoots

the expression of genes in liver HepC2 cells and (2) identify genes that could be associated with the medicinal properties of the shoot extracts.

HPLC analyses showed the presence of quercetin in the extracts of the A. occidentale shoots that confirmed earlier findings by other researchers $[19,27]$. In addition, we also detected the presence of kaempferol which has not been reported previously. Kaempferol possessed significant antioxidant activities [34] and has cancer chemopreventive properties towards several tumour cell lines including lung and leukaemic cell lines [8, 31].

In this study, cDNA microarray analysis showed that the extracts of the A. occidentale shoots at a low concentration of $0.4 \mathrm{mg} / \mathrm{ml}$ was able to significantly up-regulated $(P<0.01)$ a total of 248 genes by at least 1.5 -fold. Amongst the down-regulated genes were those encoding arsenic transactivated protein (LOC100289612), vacciniarelated kinase 1 (VRK1), dihydrofolate reductase (DHFR), cell division cycle 6 homolog (S.cerevisiae) (CDC6), cyclin-dependent kinase inhibitor $3(C D K N 3)$ and aurora kinase $\mathrm{B}(A U R K B)$. Increasing the concentrations from 0.4 to $0.6 \mathrm{mg} / \mathrm{ml}$ led to an increase in the number of regulated genes from 248 to 696. Amongst the 696 genes were CYP24A1, CDH2, E2F5, BRCA1, BRCA2, AURKA, CDC2 (CDK1), CDK2, CDK4, CHECK1, CCNA2, ACAT, IGFBPI, DUSP5 and INSR. These genes were also expressed in response to the $\mathrm{IC}_{50}$ concentration, but as expected, the fold change was much larger compared to that of the $0.6 \mathrm{mg} / \mathrm{ml}$. At an $\mathrm{IC}_{50}$ concentration of $1.7 \mathrm{mg} / \mathrm{ml}$, a total of 4286 genes were significantly regulated. In addition, the expressions of genes such as the $L G R 5, I G F B P 3, R B 1$, IDE, LDLR, MTTP, APOB, SCP2, MTIX, SOD and SOD3 
A

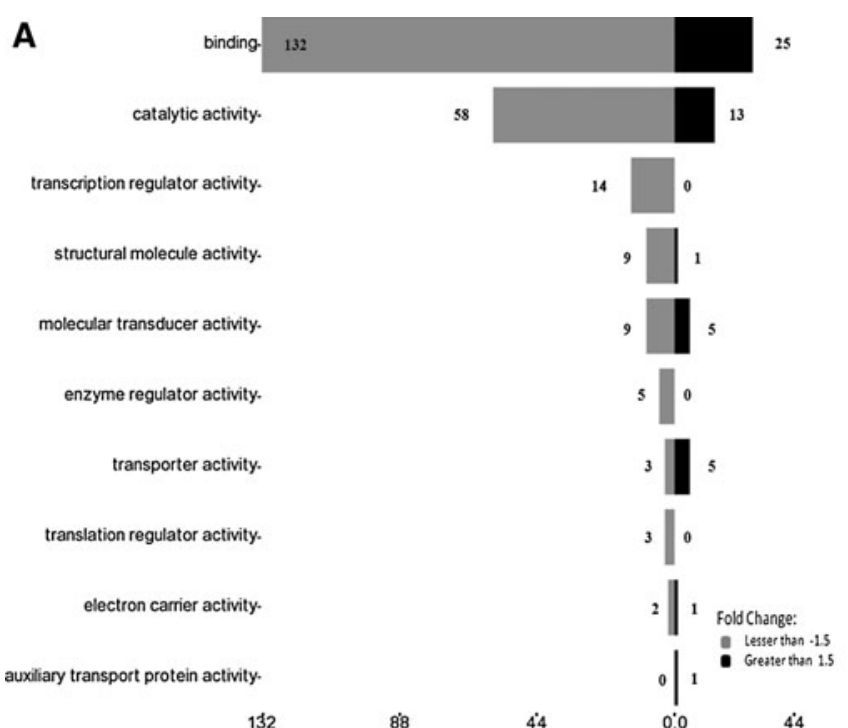

C

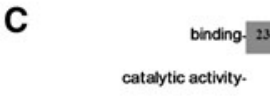

transcription regulator activity.

transporter activity.

molecular transducer activity.

enzyme regulator activity.

structural molecule activity.

translation regulator activity

electron carrier activity

auxilary transport protein activity.

proteasome regulator activity.

antioxidant activity

metallochaperone activity

chemoattractant activity.

2325

24

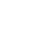

B

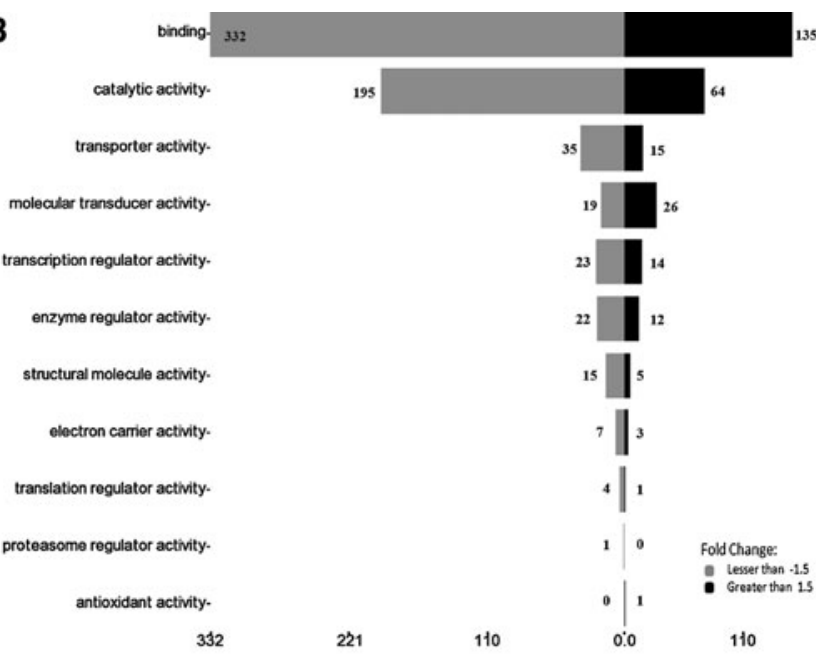

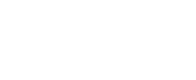
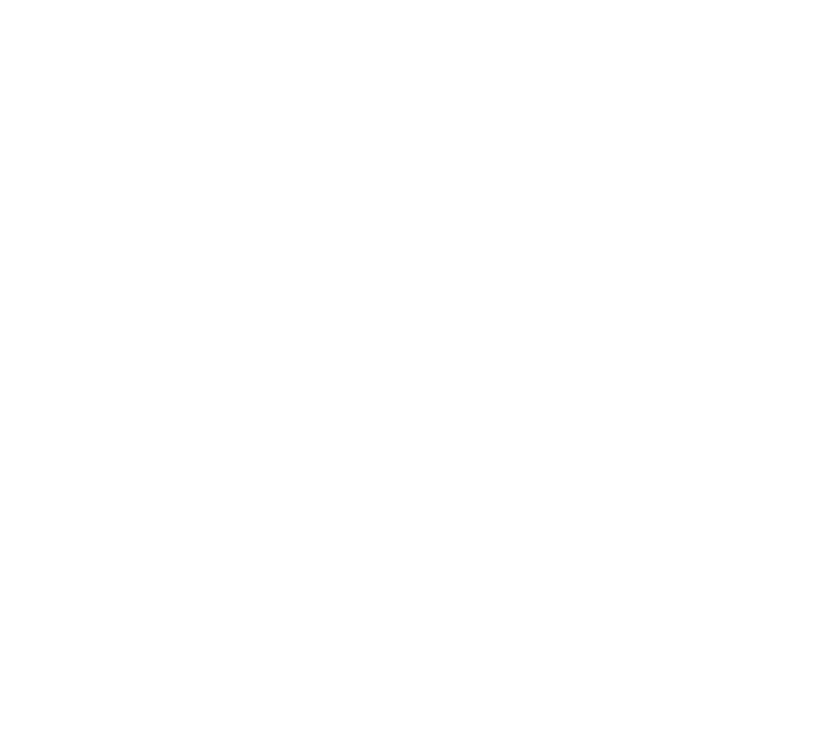

Fig. 7 Gene ontology analysis under the "Molecular function" category, of significantly regulated genes $(P<0.01$, fold change of at least $\pm 1.5)$ in HepG2 cells in response to $0.4 \mathrm{mg} / \mathrm{ml}(\mathbf{a}), 0.6 \mathrm{mg} / \mathrm{ml}(\mathbf{b})$ and $1.7 \mathrm{mg} / \mathrm{ml}(\mathbf{c})$ of the extracts of A. occidentale shoots

were exclusively regulated at the $1.7 \mathrm{mg} / \mathrm{ml}$ dose. Interestingly, for all three concentrations, the down-regulated genes were three times as many as those that were up-regulated (full data are not shown) as indicated in the hierarchical analysis. Mutually regulated genes in response to the three concentrations included CDKN3, LOC100289612, DHFR, VRK1, CDC6, AURKB, CYP2S1 and GABRE (Table 2). Amongst the highly significantly suppressed genes were CYP24A1, LGR5, CDH2 and DHFR by 27.8-, 16.4-, 15.5-, 10.0-fold, respectively. On the other hand, amongst the highly induced genes were the DUSP5, IGFBP 3, IGFBP1, LDLR and INSR by 9.1-, 8.0-, 4.2-, 3.6- and 2.6-fold, respectively.

CYP24Al gene codes for the hepatic enzyme, CYP24A1 or 24-hydroxylase which is the rate limiting enzyme in the catabolism of the active form of vitamin $\mathrm{D}, 1 \alpha, 25-(\mathrm{OH})_{2} \mathrm{D}_{3}$ or calcitriol $[18,23] .1 \alpha, 25-(\mathrm{OH})_{2} \mathrm{D}_{3}$, synthesized in the kidney by the CYP27B1, promotes dietary absorption of calcium and phosphate as well as maintain the levels of the two minerals. There are increasing evidences that individuals with low serum vitamin $\mathrm{D}$ have a higher risk of developing various types of cancers $[18,23]$ and myocardial diseases [33]. In addition, $1 \alpha, 25-(\mathrm{OH})_{2} \mathrm{D}_{3}$ is also important in regulating cell cycle check points as well as controlling multiple signalling pathways including those of the MAPK/ERK, PI3 K/AKT, Wnt and TGF- $\beta$ [5]. The CYP24Al gene has been reported to act as an oncogene and its overexpression was detected in cancers of the colon, ovary and lung $[2,18,23]$. In vivo studies have indicated that exposing cancer cells to a high concentration of the active metabolites of vitamin D stopped the cells from progressing. This occurred via a mechanism affecting cell cycle and increasing apoptosis, ultimately slowing or stopping growth of the tumour [45]. The shoot extracts of 


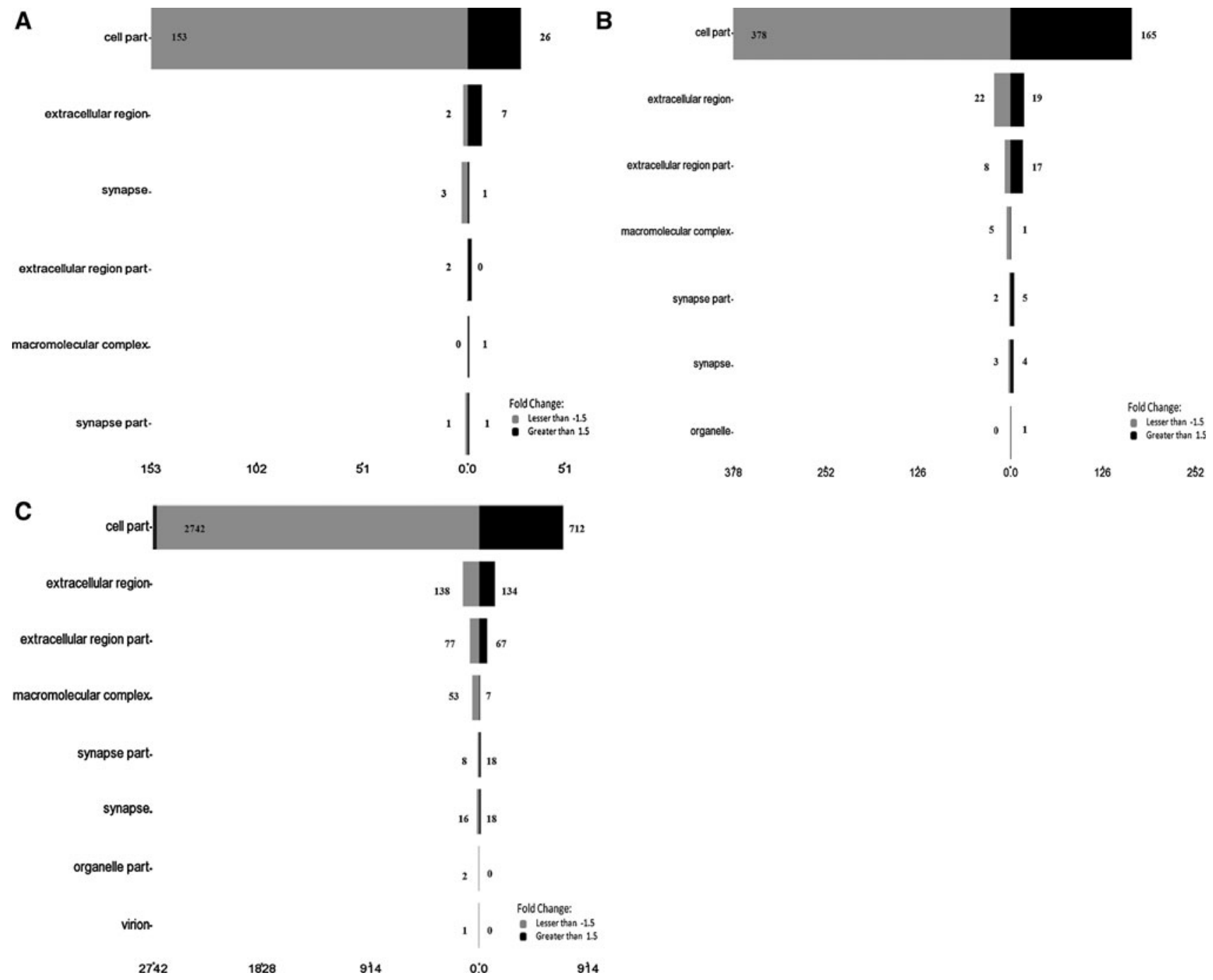

Fig. 8 Gene ontology analysis under the "Cellular component" category, of significantly regulated genes $(P<0.01$, fold change of at least $\pm 1.5)$ in HepG2 cells in response to $0.4 \mathrm{mg} / \mathrm{ml}(\mathbf{a}), 0.6 \mathrm{mg} / \mathrm{ml}$ (b) and $1.7 \mathrm{mg} / \mathrm{ml}$ (c) of the extracts of A. occidentale shoots

the A. Occidentale were able to highly suppress the CYP24Al gene; hence, it has the potential to be used synergistically with vitamin D to maintain the bioavailability and bioactivity of the latter.

Apart from the CYP24Al gene, LGR5 and $C D H 2$ were also highly suppressed, by 16- and 15-fold respectively at the $\mathrm{IC}_{50}$ concentration of the shoot extracts. The leucinerich repeat-containing $\mathrm{G}$-protein-coupled receptor 5 (LGR5) belongs to the G-protein-coupled receptor (GPCR) superfamily [15]. LGR5 had been reported to be a marker of adult stem cells where the LGR5 gene transcription is under the control of the canonical or beta-catenin Wnt signalling pathway [11]. This pathway, which is involved in embryogenesis and normal physiological processes, is critical in the regulation of adult stem cells [11, 37]. Dysregulation of this pathway is linked to cancers [37]. An overexpression of LGR5 was observed in many types of cancers including those of the colon [26, 46], oesophagus [4], ovary [26] and the hepatocytes [47]. In this study, genes associated with the $\mathrm{Wnt} / \beta$-catenin signalling pathway were also regulated at the $\mathrm{IC}_{50}$ concentration, albeit modestly. These included the Wnt6, FZDs 1, 4, 6, 7, 8, 9 and 10, CDH1, CDH2, CTNNA2, DKK1, APC, NUCKS1, CSNK1G2, CSNK1G3 and TCF (data not shown).

One of the most interesting observations of this study was the fact that the shoot extracts were able to directly regulate a spectrum of genes involved in the G1 as well as $\mathrm{G} 2$ cell cycle check points. These included the $C D K 1$ (CDC2), CDK2, CDK4,CDK5, CDK6, CCNA2, CCNB1 and 2, CCNE1 and 2,CCNH,CDKN1A (p21/Cip1), $C D K N 1 C$ (p57/Kip2), CDKN2B (p15), CDKN2D (p19), CDKN3, RB1, RBL1, RBL2, NSUN6, NOP2, AURKA, $A U R K B, D A P K 1, P A K 2, E 2 F 5, H D A C 2, V R K 1, C R E B$ and $G 2 E 3$. Genes coding for other ubiquitin ligase isoforms, 
Table 3 Gene ontology analysis of selected significantly regulated genes

\begin{tabular}{|c|c|c|c|}
\hline $\begin{array}{l}\text { (A) Gene ontology } \\
\text { (Biological } \\
\text { process) }\end{array}$ & \multicolumn{2}{|c|}{ Selected down-regulated genes } & Selected up-regulated genes \\
\hline Cellular process & \multicolumn{2}{|c|}{$\begin{array}{l}\text { CYP24A1, DHFR, CDH1, CDH2, CDC2, CDK2, CDK4, CDK5, } \\
\text { CDK6, CDKN3, CCNA2, CCNB1, CCNB2, CCNE1, CCNE2, } \\
\text { CHEK1, RB1, AURKA, AURKB, BRCA1, BRCA2, IDE, LIPC, } \\
\text { MTTP, SCP2, APOB, ACAT1 }\end{array}$} & DUSP5, INSR, IRS2, SOD2, SOD3, LDLR \\
\hline $\begin{array}{l}\text { Biological } \\
\text { regulation }\end{array}$ & \multicolumn{2}{|c|}{$\begin{array}{l}\text { CDH1, CDC2, CDK2, CDK4, CDK5, CDK6, CDKN3, CHEK1, } \\
\text { CCNA2, CCNB1, CCNB2, CCNE1, CCNE2, E2F4, AURKA, } \\
\text { RB1, CKS1B, PAK2, BRCA1, BRCA2, CSNK1G3, FZD4, FZD6, } \\
\text { LIPC, APOB, APOBEC3F, APOH, MTTP, IDE }\end{array}$} & $\begin{array}{l}\text { CDH4, CDKN2B, CDKN1A, APC2, IRS2, WNT6, } \\
\text { FZD1, FZD7, FZD8, FZD9, FZD10, IGFBP1, } \\
\text { IGFBP2, IGFBP3, IGFBP6, INSR, LDLR, SOD2 }\end{array}$ \\
\hline Metabolic process & \multicolumn{2}{|c|}{$\begin{array}{l}\text { CDH1, CCNH, CHEK1, CDK5, E2F4, CYP24A1, RB1, DHFR, } \\
\text { BRCA1, LIPC, MAOB, MTTP, SCP2, ACAT1, APOB }\end{array}$} & APC2, SOD2, SOD3, INSR, LDLR \\
\hline $\begin{array}{l}\text { Response to } \\
\text { stimuli }\end{array}$ & \multicolumn{2}{|c|}{ BRCA1, BRCA2, CHEK1, CDK5 } & $\begin{array}{l}\text { IRS2, CDKN2D, SOD2, SOD3, CDKN2B, } \\
\text { CDKN1A, MT1X }\end{array}$ \\
\hline $\begin{array}{l}\text { Establishment of } \\
\text { localization }\end{array}$ & \multicolumn{2}{|c|}{ LIPC, MTTP, SCP2, APOB } & LDLR \\
\hline $\begin{array}{l}\text { Developmental } \\
\text { process }\end{array}$ & \multicolumn{2}{|c|}{$\begin{array}{l}\text { CDH2, RB1, CCNB2, BRCA1, SCP2, FZD6, CDK6, BRCA2, } \\
\text { CCNF, DKK1, CDK5 E2F4, IDE, APOB, CDH1, FZD4 }\end{array}$} & $\begin{array}{l}\text { FZD7, CDK5R1, FZD9, IRS2, IGF2, CDKN2D, } \\
\text { FZD10, CDKN1C, SOD2, FZD8, WNT6, FZD1, } \\
\text { INSR }\end{array}$ \\
\hline $\begin{array}{l}\text { Multi-organism } \\
\text { process }\end{array}$ & \multicolumn{2}{|l|}{ RB1 } & INSR, LDLR \\
\hline $\begin{array}{r}\text { Biological } \\
\text { adhesion }\end{array}$ & \multicolumn{2}{|c|}{ CDH2, FZD6, CDK5, CDH1 } & $\mathrm{CDH} 4$ \\
\hline $\begin{array}{l}\text { Reproductive } \\
\text { process }\end{array}$ & \multicolumn{2}{|c|}{ SCP2, BRCA2, CHEK1, APOB } & \\
\hline $\begin{array}{l}\text { Multicellular } \\
\text { organismal } \\
\text { process }\end{array}$ & \multicolumn{2}{|c|}{ APOH, ACAT1, CDK5, E2F4 } & FZD9, LDLR \\
\hline Rythmic process & \multicolumn{2}{|l|}{ CDK4 } & - \\
\hline Growth & \multicolumn{2}{|c|}{$\mathrm{CCNB} 2, \mathrm{BRCA} 2$} & - \\
\hline Pigmentation & \multicolumn{2}{|l|}{-} & SOD2 \\
\hline \multicolumn{2}{|l|}{$\begin{array}{l}\text { (B) Gene ontology } \\
\text { (Molecular function) }\end{array}$} & Selected down-regulated genes & Selected up-regulated genes \\
\hline \multicolumn{2}{|l|}{ Binding } & $\begin{array}{l}\text { CYP24A1, CDH2, CDKN3, RB1, DHFR, CCNB1, } \\
\text { CCNB2, BRCA1, LIPC, AURKA, CDC2, } \\
\text { BRCC3, MTTP, SCP2, CDK2,CCNA2, APOH, } \\
\text { CDK6, RBL2, BRCA2, ACAT1, CDK4, CHEK1, } \\
\text { CCNE1, AURKB, CDK5, E2F4, IDE, APOB, } \\
\text { CDH1, FZD4, CSNK1G2, CCNE2 }\end{array}$ & $\begin{array}{l}\text { CDH4, IGFBP2, IRS2, FZD10, SOD2, FZD8, } \\
\text { WNT6, SOD3, IGFBP6, FOXO3, FZD1, INSR, } \\
\text { MT1X, LDLR, IGFBP3 }\end{array}$ \\
\hline \multicolumn{2}{|l|}{ Catalytic activity } & $\begin{array}{l}\text { CYP24A1, CDKN3, DHFR, BRCA1, LIPC, } \\
\text { AURKA, CDC2, MAOB, SCP2, CDK2, CDK6, } \\
\text { BRCA2, ACAT1, CCNH, CDK4, CHEK1, } \\
\text { AURKB, CDK5, IDE }\end{array}$ & SOD2, SOD3, INSR, DUSP5 \\
\hline \multicolumn{2}{|c|}{ Transcription regulator activity } & RB1, BRCA1, BRCA2, E2F4, CDH1 & FOXO3 \\
\hline \multicolumn{2}{|c|}{ Structural molecular activity } & - & WNT6 \\
\hline \multicolumn{2}{|c|}{ Molecular transducer activity } & FZD6, CDK5, IDE, FZD4 & $\begin{array}{l}\text { FZD7, FZD9, IRS2, FZD10, FZD8, WNT6, FZD1, } \\
\text { INSR, MT1X, LDLR }\end{array}$ \\
\hline \multicolumn{2}{|c|}{ Enzyme regulator activity } & CDH1, CCNE1 & IGFBP3 \\
\hline \multicolumn{2}{|l|}{ Transporter activity } & LIPC, MTTP, APOB & LDLR \\
\hline \multicolumn{2}{|c|}{ Electron carrier activity } & CYP24A1, MAOB & - \\
\hline \multicolumn{2}{|l|}{ Antioxidant activity } & - & SOD3 \\
\hline
\end{tabular}


Table 3 continued

\begin{tabular}{llc}
\hline $\begin{array}{l}\text { (C) Gene ontology } \\
\text { Cellular component })\end{array}$ & Selected down-regulated genes & Selected up-regulated genes \\
\hline Cell part & CYP24A1, LGR5, CDH2, RB1, CCNB1, CCNB2, & FZD7, CTNNA2, CDK5R1, CDH4, APC2, FZD9, \\
& E2F5, TYMS, BRCA1, LIPC, ATG4C, SOS1, & IRS2, CDKN2D, FZD10, CDKN1C, AQP6, \\
& AURKA, G2E3, CDC2, CHEK2, BRCC3, & SOD2, FOLR3, FZD8, AQP12A, SOD3, FOXO3, \\
& MAOB, MTTP, SCP2, GAS2, MTHFD1, CDK2, & FZD1, CDKN2B, CDKN1A, LRP12, INSR, \\
& CCNA2, APOH, CKS1B, RBL1, UBE2C, FZD6, & LDLR, AQP3, EGLN3, IGFBP3, DUSP5 \\
& BARD1, PAK2, CDK6, RBL2, BRCA2, CCNF, & \\
& ACAT1, CCNH, CDK4, PAK1IP1, NUCKS1, & \\
& DKK1, STAT2, CHEK1, CCNE1, AURKB, & \\
& CDK5, E2F4, DAPK1, IDE, TOP2B, BCCIP, & \\
CSNK1G3, APOB, CDH1, TET1, APOBEC3F, & \\
Extracellular region & FZD4, ACAT2, CSNK1G2, CCNE2, CDK7, & \\
Synapse & LRP1 & APC2, IGFBP2, IGF2, FOLR3, WNT6, SOD3, \\
LiPC, ATG4C, APOH, DKK1, APOB & IGFBP6, IGFBP4, IGFBP1, IGFBP3 \\
Macromolecular complex & - & CDK5R1 \\
Synapse part & SOS1 & APC2, IGFBP2, IGF2, WNT6, SOD3, IGFBP4, \\
\hline
\end{tabular}

Genes were categorized according to their involvement in biological process (A), molecular function (B) and as cell component (C)

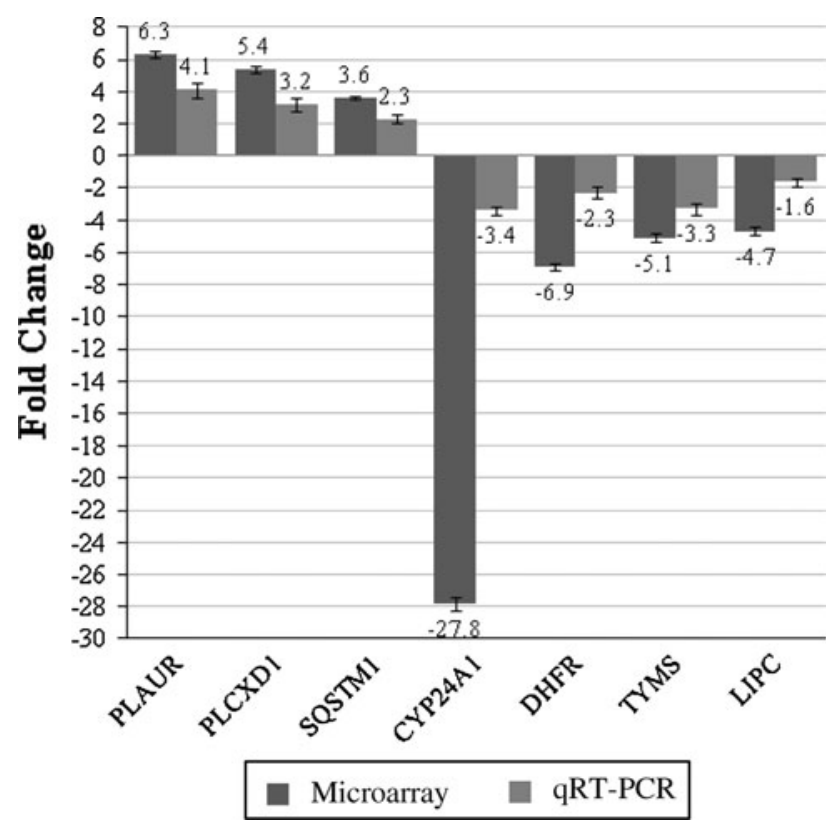

Fig. 9 Validation of the microarray data using semi-quantitative RT-PCR (qRT-PCR). A few genes that were significantly regulated in HepG2 cells in response to treatment with extracts of the A. occidentale shoots were selected namely PLAUR, PLCXD1, SQSTM1, CYP24A1, DHFR, TYMS and LIPC using real-time RT-PCR. All data were normalized to the reference gene, GAPDH. The expressions of the PLAUR, PLCXD1 and SQSTM1 genes were all up-regulated while those of CYP24A1, DHFR, TYMS and LIPC were down-regulated. The expression patterns obtained through real-time RT-PCR were consistent with the microarray results
$U B E 2 C$ and $U B E 3 B$, was also aberrantly expressed. VRK1 is involved in the regulation of DNA replication through the phosphorylation of CREB leading to the regulation of CCNDl gene expression [17].

Aurora kinases comprise three members, Aurora A, Aurora B and Aurora C. Aurora-A is transcriptionally regulated by E2F3 during a cell cycle. E2F3 induces Aurora-A expression by binding directly to Aurora-A promoter and subsequently stimulates the promoter activity [12]. Both could thus be an important target for cancer intervention [12]. In addition, aurora-B has been shown to be overexpressed in many cancers including breast cancers [10]. The methanol extracts of the A. occidentale shoots at the $\mathrm{IC}_{50}$ concentration, suppressed the Aurora $A$ and Aurora $B$, but not Aurora $C$, by fourfold and twofold respectively. An RNA methyltransferase, NSUN2 had been shown to be a novel substrate for Aurora B, which contained a NOL/NOP/sun domain [38]. In this study, the extracts were able to suppress both Aurora $A$ and Aurora $B$ as well as NOP2 and NSUN6, suggesting its potential as an anti-cancer agent.

Insulin-like growth factor binding protein-3 (IGFBP3) inhibits the growth of non-small cell lung cancer (NSCLC) cells. IGFBP3 overexpression inhibits the phosphorylation of Akt and glycogen synthase kinase- 3 beta and the activity of MAPK, all three are activated by IGF-mediated signalling pathways that have mitogenic and anti-apoptotic properties and have been implicated in the development of 
lung cancer [24]. Nuclear IGFBP3 induces apoptosis and is targeted to ubiquitin/proteosome-dependent proteolysis. IGFBP3 degradation is dependent on active ubiquitin-E1 ligase [41].

The shoot extracts also up-regulated $L D L R$ gene which correlated with findings by Salleh et al. [39] who reported that the cashew shoots were able to increase LDLR activity in cultured HepG2 cells. Other genes associated with lipid metabolism including LIPC, ACAT1, MTTP, $A P O B$ and $S C P 2$ were down-regulated. LDL-R is responsible for the internalization of cholesterol-rich lipoprotein, LDL, from the blood circulation through the recognition of its ApoB by the receptor [6]. SCP2 gene expression was reported to be enhanced by oxidized LDL [13] which could be ingested by macrophages leading to the formation of foam cells, a critical step in atherosclerosis. ACAT is responsible to convert free cholesterol to cholesteryl ester in tissues. ACAT1 is the main isoenzyme in the neuronal brain [7], and its presence is associated with certain forms of Alzheimer disease. MTTP encodes microsomal triacylglycerol transfer protein (MTP) which is required for the assembly of nascent chylomicrons and VLDL while hepatic lipase encoded by LIPC does not only hydrolyses triacylglycerols and phospholipids in circulating plasma lipoproteins, it also regulates lipoprotein uptake by cells [40]. Except for the $A C A T 1$, the expression of the $L D L R, M T T P, S C P 2$ and $A P O B$ genes was only observed in response to the $\mathrm{IC}_{50}$ concentration, not those of 0.4 and $0.6 \mathrm{mg} / \mathrm{ml}$ suggesting a concentration-dependent expression of the genes.

The anti-diabetic properties of the shoot extracts could be linked to the up-regulation of the genes coding for the insulin receptor and the down-regulation of the insulindegrading enzyme (IDE).

The hypolipidaemic, anti-diabetic and anti-cancer properties could be attributed to the presence of quercetin and kaempferol in the shoot extracts of the A. occidentale.

Quercetin and kaempferol are normally present in nature as glycosides. Free and glycoside forms of the two flavonoids are absorbed in the intestine $(9,14,48)$ and are found conjugated with glucuronides or sulphates in the blood circulation. The concentrations of the extracts selected in the study were based on MTT assays whereby cell viability was maintained above $90 \%$ at the extract concentrations of 0.3 and $0.4 \mathrm{mg} / \mathrm{ml}$. The concentrations used were probably not a true reflection of the flavonoids levels in the plasma as it was reported that the levels of free and conjugated flavonoids such as kaempferol in blood was in the range of $1.7-6.1 \mu \mathrm{g} / \mathrm{ml}$ after oral ingestion of $25-50 \mathrm{mg} / \mathrm{kg}$ body weight [48]. However, when using an in vitro model like HepG2 cells, sometimes it is necessary to use higher concentrations of extracts to see significant changes in gene expression [36]. Nevertheless, this in vitro study is still useful to provide preliminary information on the possible molecular mechanisms in relation to the medicinal properties of the shoot extracts of A. occidentale. Further confirmation using an in vivo model would need to be carried out to corroborate the in vitro findings.

\section{Conclusion}

In conclusion, low concentrations of the shoot extracts of A. occidentale were able to significantly regulate a sizable number of genes in HepG2 cells. However, the type of the expressed genes was highly dependent on the concentration of the extracts used. Amongst the genes that were significantly regulated were those involved in regulating cell cycle check points, apoptosis and cell proliferation, lipoprotein metabolism and insulin signalling suggesting the potential of the plant to act as anti-cancer, hypolipidaemic and anti-diabetic agents.

Acknowledgments This study was funded by the following research grants: E-Science Fund (12-03-02-2061) from the Ministry of Science, Technology and Innovation Malaysia (MOSTI), FRGS (FP004/2003C) from the Ministry of Higher Education Malaysia (MOHE), the UMRG (RG014/09AFR) and Research University Grants (SF076-2007A \& FR113/2007A) from the University of Malaya. We would like to thank Mr Siah Eng Tian for the technical assistance on the microarray analysis.

Open Access This article is distributed under the terms of the Creative Commons Attribution Noncommercial License which permits any noncommercial use, distribution, and reproduction in any medium, provided the original author(s) and source are credited.

\section{References}

1. Akinpelu DA (2001) Antimicrobial activity of Anacardium occidentale bark. Fitoterapia 72:286-287

2. Anderson MG, Nakane M, Ruan X, Kroeger PE, Wu-Wong JR (2006) Expression of VDR and CYP24A1 mRNA in human tumors. Cancer Chemother Pharmacol 57:234-240

3. Aziz AA, Edwards CA, Lean ME, Crozier A (1998) Absorption and excretion of conjugated flavonols, including quercetin-4'-Obeta-glucoside and isorhamnetin-4'-O-beta-glucoside by human volunteers after the consumption of onions. Free Radic Res 29:257-269

4. Becker L, Huang Q, Mashimo H (2010) Lgr5, an intestinal stem cell marker, is abnormally expressed in Barrett's esophagus and esophageal adenocarcinoma. Dis Esophagus 23:168-174

5. Brown AJ, Slatopolsky E (2008) Vitamin D analogs: therapeutic applications and mechanisms for selectivity. Mol Aspects Med 29:433-452

6. Brown MS, Goldstein JL (1986) A receptor-mediated pathway for cholesterol homeostasis. Science 232:34-47

7. Chang TY, Chang CC, Bryleva E, Rogers MA, Murphy SR (2010) Neuronal cholesterol esterification by ACAT1 in Alzheimer's disease. IUBMB Life 62:261-267 
8. Dimas K, Demetzos C, Mitaku S, Marselos M et al (2000) Cytotoxic activity of kaempferol glycosides against human leukaemic cell lines in vitro. Pharmacol Res 41:83-86

9. Gee JM, DuPont S, Rhodes MJC, John IT (1998) Quercetin glucosides interact with the intestinal glucose transport pathway. Free Radic Biol Med 25:19-25

10. Gully CP, Zhang F, Chen J, Yeung JA et al (2010) Antineoplastic effects of an Aurora B kinase inhibitor in breast cancer. Mol Cancer 9:42

11. Haegebarth A, Clevers H (2009) Wnt signaling, lgr5, and stem cells in the intestine and skin. Am J Pathol 174:715-721

12. He L, Yang H, Ma Y, Pledger WJ et al (2008) Identification of Aurora-A as a direct target of E2F3 during G2/M cell cycle progression. J Biol Chem 283:31012-31020

13. Hirai A, Kino T, Tokinaga K, Tahara K et al (1994) Regulation of sterol carrier protein 2 (SCP2) gene expression in rat peritoneal macrophages during foam cell formation. A key role for free cholesterol content. J Clin Invest 94:2215-2223

14. Hollman PC, de Vries JH, van Leeuwen SD, Mengelers MJ, Katan MB (1995) Absorption of dietary quercetin glycosides and quercetin in healthy ileostomy volunteers. Am J Clin Nutr 62:1276-1282

15. Hsu SY, Liang SG, Hsueh AJ (1998) Characterization of two LGR genes homologous to gonadotropin and thyrotropin receptors with extracellular leucine-rich repeats and a $\mathrm{G}$ protein-coupled, seventransmembrane region. Mol Endocrinol 12:1830-1845

16. Kamath V, Rajini PS (2007) The efficacy of cashew nut (Anacardium occidentale $L$.) skin extract as a free radical scavenger. Food Chem 103:428-433

17. Kang TH, Park DY, Kim W, Kim KT (2008) VRK1 phosphorylates CREB and mediates CCND1 expression. J Cell Sci 121:3035-3041

18. King AN, Beer DG, Christensen PJ, Simpson RU, Ramnath N (2010) The vitamin D/CYP24A1 story in cancer. Anticancer Agents Med Chem 10:213-224

19. Konan NA, Bacchi EM (2007) Antiulcerogenic effect and acute toxicity of a hydroethanolic extract from the cashew (Anacardium occidentale L.) leaves. J Ethnopharmacol 112:237-242

20. Konan NA, Lincopan N, Collantes Díaz IE, de Fátima Jacysyn J, Tanae Tiba MM, Pessini Amarante Mendes JG, Bacchi EM, Spira B (in press) Cytotoxicity of cashew flavonoids towards malignant cell lines. Exp Toxicol Pathol Article. doi:10.1016/j.etp.2010. 10.010

21. Kubo I, Kinst-Hori I, Yokokawa Y (1994) Tyrosinase inhibitors from Anacardium occidentale fruits. J Nat Prod 57:545-551

22. Kudi AC, Myint SH (1999) Antiviral activity of some Nigerian medicinal plant extracts. J Ethnopharmacol 68:289-294

23. Lechner D, Kallay E, Cross HS (2007) 1alpha, 25-dihydroxyvitamin D3 downregulates CYP27B1 and induces CYP24A1 in colon cells. Mol Cell Endocrinol 263:55-64

24. Lee HY, Chun KH, Liu B, Wiehle SA et al (2002) Insulin-like growth factor binding protein-3 inhibits the growth of non-small cell lung cancer. Cancer Res 62:3530-3537

25. Manacha C, Moranda C, Crespya V, Demignéa C, Texierb O, Régératb F, Rémésya C (1998) Quercetin is recovered in human plasma as conjugated derivatives which retain antioxidant properties. Febs Lett 426:331-336

26. McClanahan T, Koseoglu S, Smith K, Grein J et al (2006) Identification of overexpression of orphan $\mathrm{G}$ protein-coupled receptor GPR49 in human colon and ovarian primary tumors. Cancer Biol Ther 5:419-426

27. Miean KH, Mohamed S (2001) Flavonoid (myricetin, quercetin, kaempferol, luteolin, and apigenin) content of edible tropical plants. J Agric Food Chem 49:3106-3112
28. Mosmann T (1983) Rapid colorimetric assay for cellular growth and survival: application to proliferation and cytotoxicity assays. J Immunol Methods 65:55-63

29. Mota ML, Thomas G, Barbosa Filho JM (1985) Anti-inflammatory actions of tannins isolated from the bark of Anacardium occidentale L. J Ethnopharmacol 13:289-300

30. Mothé CG, de Souza IA, Calazans GMT (2008) Antitumor activity of cashew gum from Anacardium Occidentale L. Agro Food Ind Hi Tech 19:50-52

31. Nguyen TTT, Tran E, Ong CK, Lee SK et al (2003) Kaempferolinduced growth inhibition and apoptosis in A549 lung cancer cells is mediated by activation of MEK-MAPK. J Cell Physiol 197:110-121

32. Ojewole JA (2003) Laboratory evaluation of the hypoglycemic effect of Anacardium occidentale Linn (Anacardiaceae) stembark extracts in rats. Methods Find Exp Clin Pharmacol 25:199-204

33. Pilz S, Tomaschitz A, Drechsler C, Dekker JM, Marz W (2010) Vitamin D deficiency and myocardial diseases. Mol Nutr Food Res 54:1103-1113

34. Rao YK, Geethangili M, Fang SH, Yew-Min Tzeng YM (2007) Antioxidant and cytotoxic activities of naturally occurring phenolic and related compounds: a comparative study. Food Chem Toxicol 45:1770-1776

35. Razali NH, Razab R, Mat Junit S, Abdul Aziz A (2008) Radical scavenging and reducing properties of extracts of cashew shoots (Anacardium occidentale). Food Chem 111:38-44

36. Razali N, Abdul Aziz A, Mat Junit S (2010) Gene expression profiles in human HepG2 cells treated with extracts of the Tamarindus indica fruit pulp. Genes Nutr 5:331-341

37. Reya T, Clevers H (2005) Wnt signalling in stem cells and cancer. Nature 434:843-850

38. Sakita-Suto S, Kanda A, Suzuki F, Sato S et al (2007) Aurora-B regulates RNA methyltransferase NSUN2. Mol Biol Cell 18:1107-1117

39. Salleh MN, Runnie I, Roach PD, Mohamed S, Abeywardena MY (2002) Inhibition of low-density lipoprotein oxidation and upregulation of low-density lipoprotein receptor in HepG2 cells by tropical plant extracts. J Agric Food Chem 50:3693-3697

40. Santamarina-Fojo S, Gonzalez-Navarro H, Freeman L, Wagner E, Nong Z (2004) Hepatic lipase, lipoprotein metabolism, and atherogenesis. Arterioscler Thromb Vasc Biol 24:1750-1754

41. Santer FR, Bacher N, Moser B, Morandell D et al (2006) Nuclear insulin-like growth factor binding protein-3 induces apoptosis and is targeted to ubiquitin/proteasome-dependent proteolysis. Cancer Res 66:3024-3033

42. Sung B, Pandey MK, Ahn KS, Yi T et al (2008) Anacardic acid (6-nonadecyl salicylic acid), an inhibitor of histone acetyltransferase, suppresses expression of nuclear factor-kappaB-regulated gene products involved in cell survival, proliferation, invasion, and inflammation through inhibition of the inhibitory subunit of nuclear factor-kappaBalpha kinase, leading to potentiation of apoptosis. Blood 111:4880-4891

43. Svenningsen AB, Madsen KD, Liljefors $T$, Stafford GI et al (2006) Biflavones from Rhus species with affinity for the $\mathrm{GABA}_{\mathrm{A}}$ /benzodiazepine receptor. J Ethnopharmacol 103:22762280

44. Tesoriere L, Allegra M, Butera D, Livrea MA (2004) Absorption, excretion, and distribution of dietary antioxidant betalains in LDLs: potential health effects of betalains in humans. Am J Clin Nutr 80:941-945

45. Trump DL, Deeb KK, Johnson CS (2010) Vitamin D: considerations in the continued development as an agent for cancer prevention and therapy. Cancer J 16:1-9 
46. Uchida H, Yamazaki K, Fukuma M, Yamada T et al (2010) Overexpression of leucine-rich repeat-containing $\mathrm{G}$ protein-coupled receptor 5 in colorectal cancer. Cancer Sci 101:1731-1737

47. Yamamoto Y, Sakamoto M, Fujii G, Tsuiji H et al (2003) Overexpression of orphan G-protein-coupled receptor, Gpr49, in human hepatocellular carcinomas with beta-catenin mutations. Hepatology 37:528-533
48. Zhang WD, Wang XJ, Zhou SY, Gu Y, Wang R, Zhang TL, Gan HQ (2010) Determination of free and glucuronidated kaempferol in rat plasma by LC-MS/MS: application to pharmacokinetic study. J Chromatogr B 878:2137-2140 